NGTT Deel 54, Nommers 1 \& 2, Maart en Junie 2013

Petersen, G \& Verster, P

University of the Free State

\title{
Mission among nomads: the case of the Ovahimba
}

\begin{abstract}
Karl Barth poignantly argues that the essence of the Christian message is that God "makes time for" humanity. Nomads are people on the move. Although in tune with nature, they have a limited understanding of the God of nature. Many nomads do not recognise that the God of nature has time for them and longs to walk their cattle trails with them. In this article, the focus falls on the value of mission communication. It is argued that such communication must use the nomadic genre and recognise the oral worldview of nomads. In this way, the mission practitioner will communicate God's message more effectively. It will also be argued that immersion is necessary in order to be able to gain such knowledge. However, this immersion is not aimed at converting people; rather, its purpose is to demonstrate that God is one with nomads in their quest to connect with him. This suggests that God redeems the culture and the individual, so that, although the individual lives in the world, he is protected from the evil one. Thus, in this article, we contend that the messenger is the message that God is one with humanity - or, to quote Barth: "God makes
\end{abstract}

\section{INTRODUCTION}

In a globalised world, nomads ${ }^{1}$ are sometimes regarded as a curiosity. They are very often not taken seriously. However, there are still many nomadic groups left in the modern world. Little attention is given to their needs and aspirations. The gospel of Jesus Christ is relevant to all people - and no less to nomads. The manner in which this gospel is presented to them is crucial. This article contends that nomads can experience God as being one with them, when this possibility is demonstrated through the life of the messenger, who lives as one redeemed by God in the nomadic context.

\section{Methodology and ReSearch Questions}

The Christian mission, in general, has struggled to share the gospel with nomads. The question on which this article will focus is: How are nomadic people to hear the gospel and be discipled? In essence, the article asks the question as to whether the Christian God is indeed Immanuel, the God who comes to His people; and furthermore, whether God's missionary people are, in fact, reaching the nomadic world. The hypothesis is that what is really needed is a method focused on immersion in the nomadic culture, understanding the nomadic worldview, and using nomadic communication styles - and on achieving all this by focusing on God's goal.

1. In this article, the term "nomad" refers to a member of the original nomadic group, the pastoralists. Salzman (2004:17) explains that the original Greek term from which the concept is derived means "to raise livestock on pasture". The later, additional groups, namely the hunter-gatherers and peripatetic people, are not included. 
NGTT: Oopbron - http://ngtt.journals.ac.za

\section{WHAT IS GOD'S GOAL?}

Knowing one's goal is crucial for living in this world. The challenge facing the Christian mission is to define the end goal (telos). However, there is no general consensus among mission agencies and denominations with regard to this issue. It is not enough to define it in terms of a Western reading of the Bible. In this section, it is contended that knowing the goal from God's perspective will transform the way in which we engage in mission work.

To be effective in fulfilling the Christian mission, it is important for the mission practitioner to focus on the telos. Christopher Wright (2006:23) defines the concept, "mission", as the "long-term purpose or goal that is to be achieved through proximate objectives and planned actions". If the telos is out of focus, there is a tendency to focus on the objectives or action plans themselves. For example, mission agencies focus on reaching unreached peoples (see the U.S. Center of World Mission - www.uscwm.org). This emphasis is aimed at ensuring that all the ethnic groups (ethne) are reached, and not merely geo-political nations. This is a significant goal, and it is measurable. However, reaching the unreached does not, in itself, comprise the end goal of the Christian mission. Rather, it is a strategic objective on the basis on which action plans can be developed to achieve the telos.

Bosch (1991:349) points out that God's people do not live in a vacuum. He argues that every generation reflects the surrounding society in some way. Thus, he admonishes the present generation not to judge previous generations. He asks the pertinent question: Under the same circumstances, what would they - the current generation - have done differently (Bosch 1991:366)?

Today, the former Christian nations are moving towards a post-Christian outlook. Kraemer (1956:27) calls this "the shattering of Corpus Christianum". In the current environment, Christians are no longer in the majority; rather, Christianity has become one religion among many. Thus, Newbigin (1995:5) argues that Christians "bear witness to the gospel from a position not of strength but of weakness." It is as a result of this position of weakness that Christianity cannot afford to lose sight of the end goal.

What, then, is the telos of the Christian mission? Archbishop Emeritus Desmond Tutu states it succinctly: "God has a dream". The beloved apostle says it thus: "Behold, God's dwelling is with his people ..." (Rev. 21:3). This, Karl Barth (1956b:4-8) argues, is the essence of what God wants to achieve - to be with mankind. He always comes to humanity. Barth (1956a:45) refers to this as "God having time for us". This is his mission - missio Dei. From the beginning, God wanted to make his dwelling place with humanity. He is a God who longs to be involved in the lives of his people. The "coming" to which Barth refers, means that God wishes to be with humanity through the daily struggles of life today, and also throughout eternity. In the nomadic context, this means that he desires to walk the cattle trails with nomads. This is the Christian mission - to demonstrate that God is dwelling, and will continue to dwell, in the life of human beings both today in a tumultuous world, and in a peaceful world to come. This is God's dream.

If it is God's mission to be involved in the life of a human being, then the Christian mission entails inviting others into his presence. The presence of God is so awe-inspiring that the one entering into it will worship him. As a result of this experience, the worshipper will want others to participate in the experience, too. Thus, the worshipper is transformed; and although he lives in the world, he is connected to God and does not belong to the world (John 17:15 \& John 
15). John Piper makes an appeal to Christians to place worship above the task of conducting missions. He states: "Missions exist because worship does not" (Piper 1993:11). What Piper is suggesting is that worship should be a response to God, and that, as Christians experience God, they should be filled with awe, and inspired to bring others into his presence. This is in stark contrast to merely adopting strategic objectives or engaging in mission projects because we feel compelled to fulfil a commission. In the latter case, it becomes a duty. Piper proposes that the Christian mission should become a lifestyle, so that it becomes who we are. This would mean a lifestyle of worship, played out as an invitation to join the Creator around his throne.

It is for this reason that humanity is a witness to the universe that God has restored the broken relationship. Wenham (1987:5) argues that God desired a relationship with humanity, but that this relationship was fractured. When the relationship is restored, it brings peace (shalom) and joy. Thus, Christianity must keep God's goal in sight, if Christians are to be effective workers together with God.

Thus, the true Christian mission participates with God in the achievement of his goal. If this mission belongs to God, and it is his desire to connect with humanity, then immersion is an essential principle, since one's immersion in the world (while being connected to God) comprises a model of God's desire to connect with all humanity. Furthermore, such a goal suggests that culturally appropriate communication styles should be used, rather than Western-Christian methods. When this is achieved, Christ's prayer in John 17:15 will be brought to fruition.

\section{MisSiON BY IMMERSION}

Hunter and Phillips (2000) argue that nomads are the final mission frontier. They have remained on the margins of the Christian mission because they live in such inaccessible places; or they are overlooked, because they are so different from settled people. Van der Walt (2006) argues that the only way to come close to a people is by learning about them. Besides identifying nomads as an "unreached" people, it is important to understand who they are. This section proposes that the missionary should immerse him-/herself in the culture and community of the people whom he/she wishes to reach.

The Christian crusades were conducted with the aim of planting the Christian flag in new communities. This missionary method rippled into the 20th century in new ways. Missionaries moved from using swords to using reason as a means to persuade people of their need to choose Christianity. Here the emphasis lay in the superiority of reasoning, forgetting that different community's reason in different ways. Hiebert (2008:310) argues that such methods only address the cognitive aspect of culture - they are not holistic. This missionary method portrays God as superior, vengeful and forceful, and is not in keeping with the message that God desires to be present. God is indeed a superior being. He is also stern and powerful. However, he is a God of love. He does not use such methods to persuade people to believe in him. Rather, his aim is to remind humanity that he watches jealously over them, revealing his love and mercy. Thus, he sent his son into the world, so that humanity would not flee from his presence. God became a man in the person of Jesus of Nazareth, to enable humanity to experience God as one who identifies and connects with humanity.

Samuel Escobar (2003:99) argues that there is only one who can rightfully be described as "God's best missionary" and a "true model for Christian mission". Escobar identifies this "true 
NGTT: Oopbron - http://ngtt.journals.ac.za

model" as Jesus of Nazareth, the son of God. Jesus never cajoled people into discipleship. Ellen White (1905:143, emphasis added) states: "The Saviour mingled with men as one who desired their good". Christian missionaries need to follow the model provided by Jesus. He came with an attitude of humility and love.

Jesus modelled an important mission principle: the ability to identify closely with the people while retaining his connection with God. Thus, he could love those who hated him. He had compassion on those who were suffering. When people reviled him, he demonstrated peace. He lived in the world; but, being connected to God, he could live a different kind of life in a world of oppression and suffering. It is this example that is of great value to the missionary when working among nomads.

\section{ReDEeming THE WORLDVIEW}

Nomads are a contented people. They do not desire an alternative lifestyle (Phillips 2001:38). Their lifestyle is in keeping with their worldview. As a missionary, Jesus did not address people through power, i.e. he did not attack them (Escobar 2003:107 \& 110). Rather, he demonstrated that a life connected to God can be fulfilling and complete, regardless of the culture. That is, humanity can be connected to God even while living in the land that has been usurped by the devil.

A worldview can be defined as "an integrated, interpretive set of confessional perspectives on reality which underlies shapes and motivates and gives direction and meaning to human activity" (Van der Walt 1994:39). The interpretive perceptions are assumptions that are made by an individual. The concept of a "worldview" is often explained by means of a comparison to a pair of glasses through which one views the world. Van der Walt argues that the "glasses" are embedded in reality (one's lived world); and one's interpretation of this lived world is what gives shape to how one interacts with, or views that reality. The "glasses" will be tinted by the interpretation one gives to reality; and this interpretation is based on the assumptions (or perceptions) one makes. Thus, one's worldview shapes one's values. Values in turn shape one's thinking and behaviour - and these shape one's culture. This description is commonly referred to as the "onion model" of the worldview. In peeling the layers off, the core is discovered - comprising the worldview assumptions. (See figure 1, below, for an adaptation of the Trompenaars model of culture.)

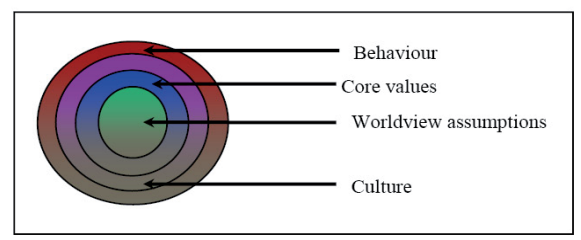

Figure 1: Worldview onion model

(Source:http://www.grin.com/object/document.56045/44bf19676360127675713893f14a6456_LARGE. png)

The worldview assumptions lie at the heart of an individual, and of society. These assumptions direct the path that people take to seek fulfilment in reaching their purpose as a people, or as individuals. Jesus demonstrated the importance of addressing worldview assumptions. He used many diverse illustrations and communication styles when addressing his audience. He 
sought to address the underlying "heart need". If the worldview is to be addressed, it must be redeemed, for missionaries are agents of redemption. Thus, the missionary's message must challenge the individual at the core of his/her being; and the response must be one of wholehearted change. Khazanov discovered that there are few similarities across the nomadic world. Nomads differ from region to region (Khazanov 1983:15). Knowing a specific people becomes important with a view to redeeming their worldview.

Redeeming the nomadic worldview implies that a Christian worldview exists. It is important that the mission practitioner should define the latter. Besides the cultural worldview - for example, the Korean culture - the missionary must also clearly define his/her Christian worldview. In defining his/her Korean-Christian worldview, for instance, the mission practitioner needs to identify the biblical assumptions on which this worldview is based. He or she should then highlight these assumptions, and allow the convert to redefine his/her nomadic worldview from a biblical perspective. Thus, the convert forms a nomadic-Christian worldview of life. It was for this reason that Father Donovan felt the need to share the gospel and then depart, in order to open the way for the Holy Spirit to teach the Masai the essential Christian principles pertaining to their own particular context (Donovan 1982).

The worldview redemptive model challenges nomads about their own worldview assumptions, enabling them to respond in appropriate ways to their environment (physical, social, mental and spiritual). This approach is aimed at redeeming the heart of the people and, through the resulting connection to God, allowing the Holy Spirit to teach his principles of truth so that the host culture can be redeemed. This comprises a slight departure from Hiebert's (2008) proposal for a worldview transformation. Hiebert is cautious in his approach towards defining transformation. He states: "We need to return to a biblical view of transformation, which is both a point and a process; this transformation has simple beginnings but radical, lifelong consequences" (Hiebert 2008:310). The theological term, "to redeem", means to reclaim something. The term therefore implies that the worldview has an original that has been distorted. Thus, the premise of this study is that God comes to people in their specific context. God never uproots a people with a view to inducing them to change their identity. Rather, he enters a person's world and grafts him or her to himself (John 15 \& Rom. 11:16-24) for building and developing those around (Eph. 4). Thus, when God comes to a people, he seeks to make them his own, while retaining their identity as an individual. This can be illustrated as follows:

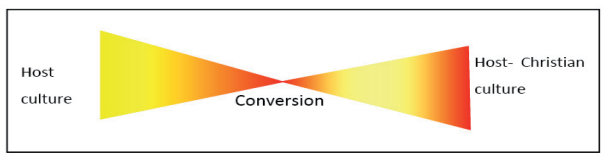

Figure 2: Worldview redemption model

The worldview redemptive model proceeds from the premise that sin has distorted all cultures. Hence, the assumptions that nomads make about life are distorted, and redemption is a necessity - as in the case of all people. This redemption entails the sharing of the gospel in packaging that is familiar to the people. The presentation of the gospel cannot bring about salvation from sin if the people have no understanding of sin. The good news must address their core underlying perceptions of life. These perceptions are to be challenged in such a way that the gospel of Jesus can be presented as the appropriate response to life's perplexing 
NGTT: Oopbron - http://ngtt.journals.ac.za

challenges. Once this is achieved, a conversion takes place, in which the convert places God at the centre of life. In so doing, the convert seeks to listen to God's answers to life's challenges, as opposed to traditional answers. For the nomad, this entails a choice between self-sufficiency and realising that God can provide for all his/her needs. Thus, the convert moves towards a Christian culture in the context of his/her lived world. This enables him/her to bear witness that God can transform a life in that context.

\section{Communicating the gospel in a nOMAdic EnVironment}

Basic communication theory (of which the fundamental elements are the speaker, message and audience) suggests that communication is about good oration (see Søgaard 1993:30). Mission communication must transcend this understanding, for it must be "rooted in God's nature" (Søgaard 1993:11). Yet Hesselgrave's (1991:536) warning, namely that the missionary should be careful regarding the technology that he/she introduces, has significance, since foreign technology has implications for the host community. Mission communication entails more than technology or media - it is about relationships. This aspect appeals to nomads, since communication in their life context is based on experience in a relationship, rather than on words per se. In terms of their worldview regarding communication, the sender and the messenger have as much value as the message. The value and application of the message will depend on the relationship between the recipient and the sender. In mission communication, the missionary is the messenger. God sends the message through the messenger. God is, therefore, the sender. The question is, what relationship, if any, exists between God and nomads? Secondly, what is God's message to nomads? Thirdly, how is that message to be shared? Some answers to these questions will be provided in the following paragraphs, in the context of the Ovahimba² of Namibia.

Christian missionaries need to earn the right to be heard. The missionary cannot enter a community as one who knows and understands life in the nomadic context. Rather, he/ she must enter as a learner. This is especially true among nomads. There is a vast difference between a sedentary person and a nomad. Therefore, entering the nomadic community as a learner is vital. It requires interaction, and not mere book knowledge. Taking the time to be with the people, in order to learn about their world and who they are, has value. This entails immersing oneself in their culture so that one can be an adopted member. This will demonstrate humility.

In a nomadic environment, immersion entails learning new ways to understand concepts such as climatology. Familiarity with weather patterns enables nomads to make judicious decisions in terms of where to move their animals. Understanding the important role that biology plays in the life of a nomad is a significant factor. Biology provides nomads with their food and medicine. Thus, learning to know from a nomadic perspective - rather than coming with prior knowledge - will demonstrate a connectedness to the people (see Donovan 1982:16). Neither should one's experience be centred in the nomads' religious world. Rather, a holistic understanding of the people will allow a bond to develop between missionary and nomad. This is achieved through immersion, which, in turn, gives the missionary the opportunity to be heard.

2. The Ovahimba are a nomadic people living in northwest Namibia. ("Ovahimba" is the plural form; the singular "Himba".) Dr Gideon Petersen ministered to the Ovahimba in Opuwo for 16 years. The references to their worldview and culture are based on his experience. 
Father Vincent Donovan modelled this approach as he worked among the Masai. He desired to be "cut off" from the mission station and Western influence (Donovan 1982:16). To achieve this, he went on "safaris". He distanced himself from the mission station and adopted a nomadic lifestyle as an itinerant preacher. Phillips (2001:46-47) confirms that following a nomadic lifestyle is the only way to earn the right to be heard in this context. It was only as he immersed himself in the context that Donovan succeeded in connecting with the people. Thus, his lifestyle allowed him to communicate the gospel meaningfully to the Masai. It is this kind of immersion that is being proposed here - an immersion that allows the missionary to connect with nomads in all aspects of their lives, so that he/she can understand the nomadic worldview (or heart).

\subsection{What is the relationship between God and nomads?}

In the Himba worldview, God is distant from humanity. The worldview assumption here is that God is spirit, while humanity is flesh and blood. These cannot come together. For the Himba, only the "living dead" or ancestors (who are spirit) can know God. This implies that the Ovahimba cannot know $(u a z u)^{3}$ God, because he does not interact with humanity. It is this perception of God that must be questioned; and the way in which God is involved in the life of a Himba person needs to be demonstrated. The coming of God to the Ovahimba so that they can experience him will be a significant factor.

According to the Himba worldview, it is simply not possible for a person to be connected to God. As pointed out above, the worldview assumption or perception is that God is a spirit and cannot be approached by humanity. Addressing worldview perceptions such as this one will entail the demonstration of a different way to respond to life's challenges. Jesus addressed people's hearts, rather than focusing on issues, doctrine or lifestyle (John 4:7-15 \& 8:3-11). He challenged people's worldview perceptions and introduced a God who desired to connect with humanity in a personal way. Through this unique view of God, Jesus redeems the whole person - including his/her worldview.

It is important to understand that the Ovahimba view God as the Creator. However, they believe that he is uninvolved in the world. Therefore, their trust in God is very low. A nomadic world is based on experience; and thus, there is a need for God to enter the nomads' world to demonstrate his trustworthiness, making it part of their experience. God, however, chooses to send a human representative as a demonstration of what he can and wants to do. Thus, the messenger becomes an important medium for God to communicate his will.

\subsection{What is God's message for nomads?}

To understand God's message for the Ovahimba, it is imperative to be familiar with the Himba worldview. In this regard, the word uazu ("to know") reflects the Himba understanding of the concept of knowing. One of the characteristics of the Himba worldview, as I came to understand it, is that there seems to be an endless cycle of adding value to one's life, but always within the context of an acknowledgement that life was better in the old days - katjitwaenda. The term katjitwaenda means: "Life is not what it used to be" - i.e., life is not as good as it was in the past. Although there seems to be a striving to be all that one can be, on the one hand, there is also a yearning for the past, on the other - because life is different today. If one reflects

3. According to the Himba understanding, to "know" means to experience first-hand. One cannot hear about something and say one knows about it. 
NGTT: Oopbron - http://ngtt.journals.ac.za

on this saying, it seems to be indicative of a deeper concern that the culture is changing. This understanding of katjitwaenda points to a need to preserve as much of the culture as possible.

Since the Ovahimba are an oral society, their collective memory does not go back very far. The furthest point in their history that they can remember is the time when the people separated at Okaronda Kambeti. This story is somewhat analogous to the story of the tower of Babel in the Bible, which relates how people separated and went in different directions. However, in the case of the Ovahimba, the people from whom they separated were - and still are people whom they know, such as the Ovathemba and Ovambo. In sharing God's message, it is important to acknowledge that there was once a time when all people lived in harmony. It is to this time that the Ovahimba long to return; and it is this experience that God longs to give them.

A second important worldview principle for the Ovahimba is that of inheritance. The Ovahimba have a double descent, one branch of which is spiritual and the other material. The spiritual legacy is passed down through one's father. This inheritance is concerned with ways of living. It guides one in living as a member of the omuhoko (family) or community. The material descent is passed on through one's mother. Here, the primary inheritance is cattle. God's message transcends the material and the spiritual inheritance. However, it links up with the idea that life is not the same as it once was. God wants to give the Ovahimba an inheritance that is lasting, and restore them to a state where harmony reigns among humanity, as it did at a particular time in the past. This time refers back to when humanity had a connection with God; that is, when no barrier separated humanity from God. The message for the Ovahimba, then, is that God wants to be reconciled with humanity, so that they can receive their true inheritance, which will lead to the harmony and togetherness that they long for.

\subsection{A medium for the message}

In oral societies, the medium used by the sender is significant. Often, the message will be delivered by a messenger, who chooses the way in which the message is to be conveyed or delivered. The content of the message will determine the delivery style. However, the recipient will also determine the style. Here, two mediums are identified: the messenger and the delivery.

According to McLuhan and Fiore (1967), "the medium is the message". For nomads, the messenger is an extension of the message. This is reflected in the value that the sender places on the message. If a child is sent, the message has minimal value. (The messenger is a medium). It is at this point that a mission of immersion becomes valuable. This is because immersion is a form of communication - it is a message. One cannot communicate the coming of God to a people without being one with them. This entails knowing and understanding what it means to walk their cattle trails, for example. Here, the message and the life must demonstrate God's desire to be connected with people. The messenger, as a person reconciled to God, communicates the value of being a human being in a degraded world. Through immersion, the degree of interference in the communication process is significantly reduced. This approach to communication can be illustrated as follows: 


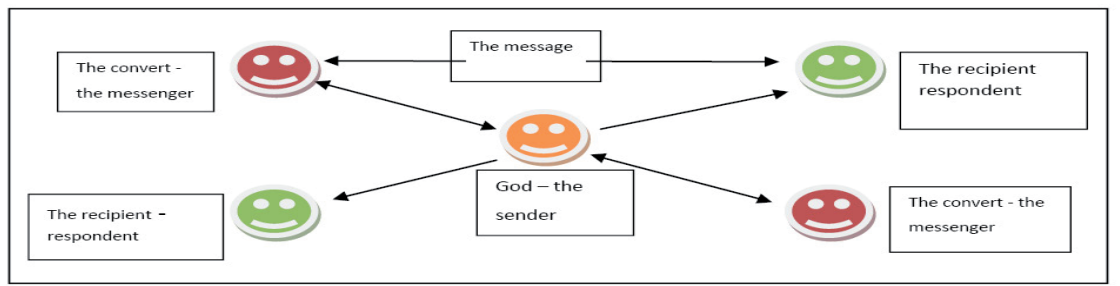

Figure 3: The messenger as medium (adapted from Hesselgrave 1991:108)

Throughout God's communication with the world, he applies this principle. He communicates his love through a messenger, making it known that he wants to reconnect with people. Thus, the messenger becomes the medium. When humanity turned away from God in the Garden of Eden, it was God who came and sought after them (Gen. 3:8ff). The medium demonstrated God's desire to reconnect with humanity. When Jesus came to earth, he came as God incarnate. Again, the medium is the message. When Jesus returned to heaven he instructed his disciples to wait for the Holy Spirit so that they could receive power to be witnesses of God's redeeming power. The Holy Spirit works through the messenger as a demonstration of the power of God to redeem the life of a human being. The messenger's role is to introduce another human being to God, who will redeem that person.

As people with an oral tradition, nomads place a high value on experience and modelling, since it is through these aspects that learning takes place. Thus, the life of the messenger is the greatest testimony of what God can - and desires to - achieve. The messenger is the medium; and the message is a redeemed life connected to God.

To complete the communication delivery, the medium is important. In the Western Christian tradition, preaching has, for the most part, comprised the medium. Preaching challenges nomads, as it means stepping outside of their habitual space and entering a new space - the church building. Where buildings are not used, a tree is often used to represent the church building. Preaching also implies that a monologue comprises communication, whereas nomads usually engage in dialogue. To preach implies reading from the Bible. But nomads are oral people. Preaching itself is a style of delivery that is unfamiliar to nomads. It is not a genre common to their experience.

This raises significant challenges. These challenges can only be met as the missionary immerses him-/herself in the culture. Learning the local communication styles should be a priority. The genre must be understood. Moreover, the places of sharing must be understood, as well as the appropriate time for sharing. Bruce Olson highlights these aspects meaningfully in his discussion of his experience among the Motilone Indians. Although he was anxious to share 
NGTT: Oopbron - http://ngtt.journals.ac.za

the gospel, he had to wait for his first convert to lead the way in this regard. After a year, the time was right and the place was right (Olson 2006). The messenger used the appropriate genre, at the appropriate time, at the appropriate place, with the appropriate people. As a result of his sharing, the tribe accepted the story of Jesus.

In working among the Ovahimba, it was difficult, at first, to master the Himba genre. Poetry is said to be an important genre for oral people. Often, poetry (omiimbo) is chanted. The Ovahimba have other genres as well. They use praise songs (ombimbi), which are reserved for heroes or brave men. They also engage in ondjongo (a dance), mainly in order to share stories. Initially, ongano (fairytales) seemed to be an appealing genre for mission work. These are used by older people when communicating important values to children around the family hearth at night. After further research had been conducted, however, it was realised that ongano would not fit the message, and would, in fact, reduce the value thereof. An initial recording was made, in which Bible stories were related, using omiimbo and ondjongo. The responses from Christian leaders included the following: "I did not know that Christians can use tradition... I thought to be Christian meant to be Western ...; and: "This is how our parents will hear the gospel.... After a second recording was made, using drama, ombimbi and omiimbo, a Himba man commented: "You really want to reach the hearts of our people, don't you?" Using a local genre touches the heart of those whom one wishes to reach. It indicates that the sender values the message... and also that the sender values the audience.

Although the use of a familiar genre speaks to the heart, the message is also important and must be communicated. At this point, I would like to share some steps that form part of the delivery process. I have already pointed out the importance of immersing oneself in the culture and becoming familiar with it. From the usual Christian perspective, the next step would be to share the gospel story. In terms of a worldview redemptive model, however, this would be a mistake. Using a familiar genre, one must challenge the worldview assumptions first. Jesus did this. When Nicodemus visited him, Jesus did not answer his question; rather, he addressed the underlying question that he did not verbalise (John 3:1-21). It is at this worldview level that nomads must be jolted and allowed to feel a little uneasy. Once a nomad has been challenged regarding his/her worldview, an appropriate answer must be presented with a view to restoring the broken trust in God. This entails an invitation to enter God's presence. In doing so, one's human frailties will be recognised; yet God will open one's eyes to see the human potential that can be released when one is connected with him. Thus, God's call for humanity to enter his presence is aimed at making them complete - for, in God, human beings exist, move and have their being. The traditional worldview assumptions give a false peace and sense of assurance, even though they appear to provide the answers to life's pressing questions.

Once the convert has made a decision to be reconciled to God, it becomes important to share ways to connect with God. This will be a new experience for the convert - connecting with someone whom he/she does not know. It is thus important to share spiritual habits that will help the convert to make the connection. Prayer is an important practice among the Ovahimba. Usually it entails talking to an ancestor, who in turn speaks to God. Now the convert can speak directly to God without a mediator. This will be a new experience that will need some guidance. Bible study, as a spiritual practice, is an important Western way of connecting with God. Christian doctrine, however, reminds us that God speaks through nature, as well as through the written text. Connecting with God through nature should not be difficult for nomads, who are totally immersed in their natural environment. Helping them to see God in 
nature will thus be a significant factor. Finally, new converts will need to be nurtured. They need to mature as people reconciled to God. This must happen in the context of their worldview. Biblical principles must be shared by addressing and challenging worldview assumptions. There may be some premises that are common to both biblical principles and worldview assumptions; for example, the idea of community is an important biblical principle. However, other worldview assumptions may be in conflict with biblical principles; for example, that of including the dead as part of the community. The right choice in terms of how to deal with such assumptions will need to be impressed upon the converts by the Holy Spirit.

In the light of the foregoing, it is clear that the gospel needs to be presented to nomadic peoples within their own familiar context. Donovan (1982:16), when sharing with the Masai, did not wish to use his preconceived biblical teaching to interpret the Bible for the people. It is this attitude that needs to be embraced. The steps in the process of communication delivery are illustrated in Figure 4 below.

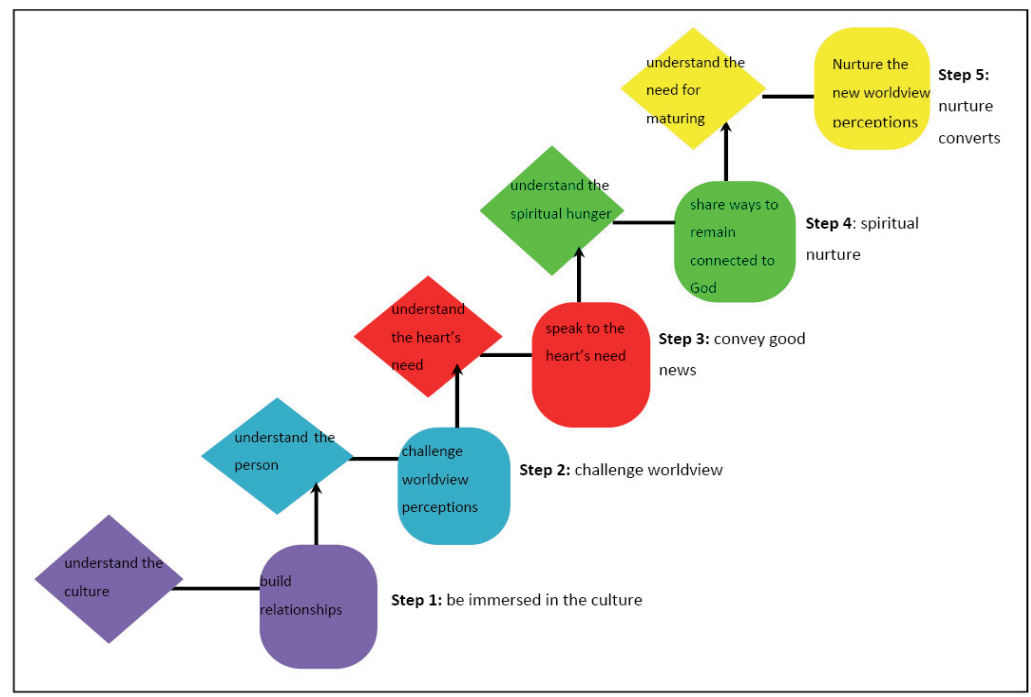

Figure 4: Steps in communication delivery

Mission communication in a nomadic environment must speak the "heart language" of the people, and address their worldview assumptions. This will give value to the message, while also according value to their culture and lifestyle. Thus, the medium used demonstrates God's telos - his desire to connect with humanity.

\section{CONCLUSION}

Søgaard (1993:12) correctly states that "God is by nature a communicator". This article argued that God wants to communicate with nomads through his messengers, using nomadic communication styles. He wishes to do this so that nomads can know that he desires to relate to them personally. The article proposes a worldview redemptive approach. Such an approach 
NGTT: Oopbron - http://ngtt.journals.ac.za

is focused on enabling nomads to experience God as being one with them.

\section{REFERENCES}

Barth, K. 1956a. Church Dogmatics I: The doctrine of the Word of God 2. (translated by GW Bromiley). New York: Charles Scribner \& Sons.

1956b. Church Dogmatics IV: The doctrine of reconciliation 1. (translated by GW Bromiley). New York: Charles Scribner \& Sons.

Bosch, D.J. 1991. Transforming mission: paradigm shifts in theology of mission. Maryknoll, NY: Orbis Books.

Donovan, V.J. 1982. Christianity rediscovered: an epistle from the Masai. London: SCM Press.

Escobar, S. 2003. The new global mission: the gospel from everywhere to everywhere. New York: Orbis Books.

Hesselgrave, D. 1991. Communicating Christ cross-culturally: An introduction to mission communication. $2^{\text {nd }}$ ed. Grand Rapids, Ml.: Zondervan.

Hiebert, P.G. 2008. Transforming worldviews: an anthropological understanding of how people change. Grand Rapids, Ml.: Baker Academic.

Hunter, M. and, Phillips, D.J. 2000. Editorial: "Reaching the last frontier". International Journal of Frontier Missions, 17:2 (2000): 3-4 \& 52.

Khazanov, A.M. 1983. Nomads and the outside world. Madison, Wl.: University of Wisconsin Press.

Kraemer, H. 1956. The Christian message in a non-Christian world. London: James Clarke \& Co.

McLuhan, M. and Fiore, Q. 1967. The medium is the message: an inventory of effects. San Francisco: Hardwired.

Newbigin, L. 1995. The open secret: an introduction to the theology of mission. Grand Rapids, MI.: Eerdmans.

Olson, B. 2006. Bruschko: the astonishing true story of a 19 year old American, his capture by Motilone Indians and his adventures in Christianizing the stoneage tribe. Lake Mary, FL.: Charisma House.

Petersen, G.P. 2011. Ministry to nomads: a comprehensive missiological approach. Bloemfontein: University of the Free State. (PhD).

Phillips, D.J. 2001. Peoples on the move: introducing the nomads of the world. Carlisle, UK: Piquant.

Piper, J. 1993. Let the nations be glad: the supremacy of God in missions. Grand Rapids, MI.: Baker Book House.

Salzman, P.C. 2004. Pastoralists: equality, hierarchy, and the State. Cambridge, MA: Westview Press.

Søgaard, V.B. 1993. Media in church and mission: communicating the gospel. Pasadena, CA: William Carey Library.

Trompenaars, F. 2011. [Online]. Available from: http://www.grin.com/object/document.56045/44bf1 $9676360127675713893 f 14 a 6456$ LARGE.png [Accessed 4 July 2011].

Tutu, D. 2004. God has a dream. Parktown: Random House South Africa.

Van der Walt, B.J. 1994. The liberating message: a Christian worldview for Africa. Potchefstroom: Institute for Reformational Studies. 2006. When African and Western cultures meet: from confrontation to appreciation. Potchefstroom: Institute for Reformational Studies.

Wenham, G.J. (ed.). 1987. Word Biblical Commentary, vol. 1 (Gen. 1-15). Dallas, TX: Thomas Nelson.

White, E.G. 1905. Ministry of healing. Mountain View, CA: Pacific Press Publishing Association.

Wright, C.J.H. 2006. The mission of God: unlocking the Bible's grand narrative. Nottingham, UK: Intervarsity Press.

\section{KEY WORDS}

Mission

Nomads

Communication

God's way

Worldview

\section{Contact details}

Dr Gideon Petersen,

Research Fellow,

Department of Missiology, 
NGTT Deel 54, Nommers 1 \& 2, Maart en Junie 2013

Faculty of Theology,

University of the Free State.

e-mail: 21.3thedream@gmail.com

Prof. Pieter Verster,

Head of the Department of Missiology,

Faculty of Theology,

University of the Free State.

e-mail:versterp@ufs.ac.za 